\title{
Terrane evolution of the paratectonic Caledonides of northern Britain
}

\author{
H. A. ARMSTRONG ${ }^{1}$ \& A. W. OWEN ${ }^{2}$ \\ ${ }^{1}$ Department of Geological Sciences, University of Durham, Durham DH1 3LE, UK \\ (e-mail: H.A.Armstrong@durham.ac.uk) \\ ${ }^{2}$ Division of Earth Sciences, University of Glasgow, Gregory Building, Glasgow G12 8QQ, UK
}

\begin{abstract}
A stratigraphically constrained re-evaluation of terrane amalgamation in the Caledonides of northern Britain allows the development of a new orogenic scenario which accounts for many of the outstanding problems in the paratectonic Caledonides and includes a new terrane template which correlates well with that proposed for Newfoundland. The Arenig Grampian Orogeny resulted from the accretion of two arc terranes to Laurentia: the Midland Valley (=Notre Dame Arc in Newfoundland) and a terrane of probable Avalonian/Gondwanan origin, here termed 'Novantia' (= Annieopsquotch Accretionary Tract partim), now hidden beneath the Southern Uplands allochthon. The Tyrone and Ballantrae ophiolites mark the northern boundary of Novantia within the composite Midland Valley Terrane. The Popelogan-Victoria Arc-Grangegeeth Terrane accreted to the amalgamated Midland Valley Terrane during the late Ordovician and initiated the Southern Uplands thrust duplex. A brief period of northward subduction during the Silurian followed, is ascribed to the northerly drift of the amalgamated Avalon-Baltica plate, and a final Wenlock (Scandian) collision and caused underplating of the Midland Valley Terrane. Caledonian deformation had ceased by the Emsian, the age of the undeformed Cheviot lavas that overlie the uplifted and peneplaned Southern Uplands.
\end{abstract}

Keywords: Caledonides, Great Britain, Newfoundland, terranes.

A consensus has emerged that the Caledonian Orogen in Britain (Fig. 1) resulted from microplate accretion and ultimately collision between the stable cratons of Laurentia, Avalonia and Baltica (Soper \& Hutton 1984; Hutton \& Dewey 1986); this view accords well with the evolution of the Appalachian Orogen (Williams 1978; Williams \& Hatcher 1982). A minimum of seven terranes have been recognized in the British Isles (Gibbons \& Gayer 1985; Bluck et al. 1992; Murphy et al. 1991; Stone \& Kimbell 1995; Fig. 1), with two distinct phases of terrane amalgamation, during the early Ordovician, Grampian (Taconic) orogeny and during the later Ordovician to Silurian. The intervening period was characterized by the opening and closure of marginal basins and arc rifting events. The Mediterranean Sea (Pickering et al. 1988) and western Pacific (van Staal et al. 1998) have been regarded as recent analogues for the complexity inherent in the Iapetus Ocean.

Since the publication in 1995 of the thematic set of papers 'Caledonian terrane relationships in Britain' in Geological Magazine (Vol. 132), new palaeontological, geochemical and geochronological datasets have been produced from Britain, Ireland and Newfoundland. Examples include the following.

(i) A new date for the collision of the Midland Valley and Grampian terranes at c. $470 \mathrm{Ma}$ (Soper et al. 1999), has enabled a revision of the tectonostratigraphy and duration of the Grampian Orogeny (see Dewey \& Mange 1999 for a review).

(ii) Our own work in the Northern Belt of the Southern Uplands in Scotland (e.g. Armstrong et al. 1996) has indicated palaeontological and sedimentary linkage across the Southern Upland Fault.

(iii) There is convincing evidence for a continental margin setting for deposition from the Late Ordovician onwards in southern Scotland (Armstrong et al. 1998, 1999, 2000; Owen et al. 1999). (iv) Sediment provenance studies (Bluck 1983, 1984, 2000; Kelley \& Bluck 1989; Phillips et al. 1998; Armstrong \& Owen 2000) indicate a missing source to the south of the Southern Upland Fault.

(v) Crustal magnetization and high-level granite geochemistry in the Southern Uplands (Kimbell \& Stone 1995; Stone et al. 1997) indicate that a hidden terrane, herein named 'Novantia', is located beneath the Southern Uplands.

(vi) The controversial proposal, that the cover successions within the Highland Border, Midland Valley Terrane and the Southern Uplands contain a significant component derived from the Grampian Terrane (Hutchison \& Oliver 1998; Oliver et al. 2000). If this assertion is correct (see Stone \& Evans 1999 for an alternative view) then the terranes within the paratectonic Caledonides must have been situated adjacent to the Laurentian margin from the middle Ordovician and so distances between the Grampian, Midland Valley and Southern Uplands were similar to the present day.

Significant problems, however, still remain within the British paratectonic Caledonides, for example:

- the cause of the obduction of the Ballantrae Complex;

- the nature of the basement of the Southern Uplands;

- the source of andesitic detritus in southerly derived greywackes in the Galdenoch and Portpatrick formations in the Northern Belt and the Gala Group in the Central Belt of the Southern Uplands;

- the absence of Grampian flysch in the marginal basins outboard of the Laurentian margin;

- along-strike correlation of terranes between Scotland and Newfoundland.

These problems are addressed herein in the context of a re-evaluation of the orogenic history of the paratectonic Caledonides. Following the development of a new orogenic template for the British Caledonides we discuss and simplify 


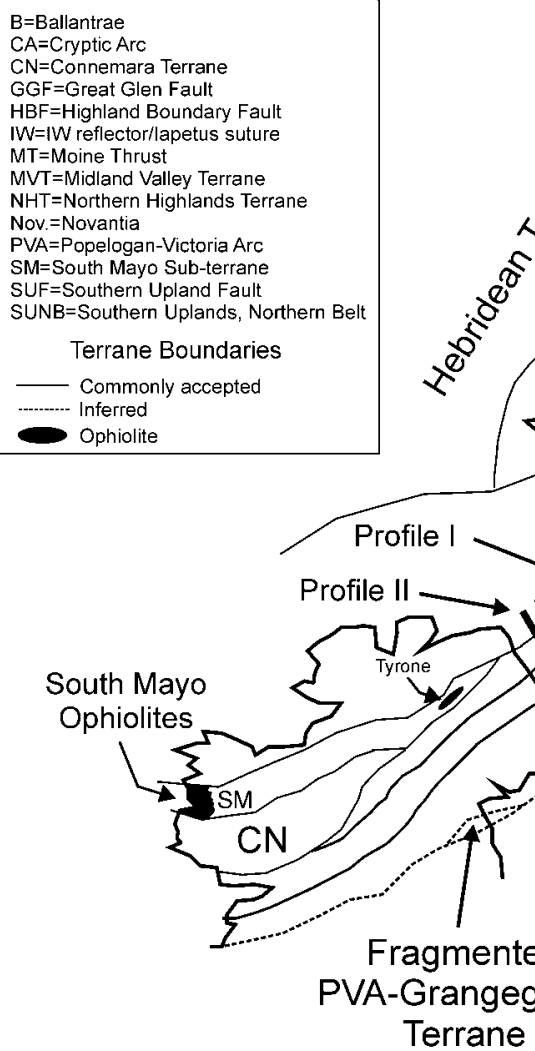

Terrane

Fig. 1. Simplified terrane map of northern Britain and Ireland (modified from Bluck et al. 1992; Stone \& Kimbell 1995). Profiles I and II are the lines of the aeromagnetic survey described by Kimbell \& Stone (1995) and used by them to construct the geophysical models redrawn in Figure 6. The inferred subduction zone along the northeast coast of England is taken from Cocks et al. (1997). the direct correlations between terranes in Britain and Newfoundland.

\section{Template development}

At the heart of our analysis is a tectonostratigraphical range chart, summarizing the geology and events within the Caledonian terranes of northern Britain and Ireland (Fig. 2).

The time ranges of events have been plotted to take account of the errors on radiometric dates. These are set against the standard British Ordovician chronostratigraphy of Fortey et al. (1995) with the series boundaries calibrated as closely as possible to the chronometric timescale (Fortey et al. 2000). Remarkably few absolute dates can be tied closely to the chrono- and biostratigraphical divisions of the Ordovician and thus it would be misleading to try to arrange finer scale divisions on this chart. However, due emphasis is placed on the relative timing of tectonic events which can be directly constrained by biostratigraphical evidence. Maps have been constructed for critical times and record a chronological sequence of events that build to produce an coherent orogenic model (Figs 3, 4, 5). Each map is a testable hypothesis that can be used to identify or predict areas of uncertainty and hence guide further research.

\section{Terranes and ophiolites south of the Highland Boundary Fault}

\section{Ballantrae and Tyrone Ophiolites}

The Ballantrae Ophiolite Complex (Church \& Gayer 1973; Bluck 1978) contains the components of an ophiolite that was thrust onto the Midland Valley, during the early Ordovician. Bluck et al. (1980) suggested that most of the volcanic rocks in the Ballantrae Complex were generated in an island-arc marginal basin setting. A U-Pb zircon age of $483 \pm 4 \mathrm{Ma}$ for a trondhjemite body dates the genesis of the ophiolite and a $\mathrm{K}-\mathrm{Ar}$ age of $478 \pm 4 \mathrm{Ma}$ on amphiboles in the metamorphic aureole, is the age of emplacement (Bluck et al. 1980). Clastic sedimentary rocks within the pillow lavas contain graptolites, indicative of an early to mid-Arenig age (Stone \& Rushton 1983), strengthening the correlation between Ballantrae and Tyrone (Hutton et al. 1985; Hutton \& Holland 1992; Rushton 1997). Chert REE profiles indicate that the complex formed close to a continental margin (Armstrong et al. 1999).

Alsop \& Hutton (1993) proposed that the main Grampian deformation in central Ireland was coeval with igneous activity in the Tyrone Ophiolite and that the Arenig-Llanvirn $\left(D_{3}\right)$ east-southeastwards thrusting of Dalradian rocks in the Sperrin Nappe-Omagh Thrust over the Tyrone Igneous Complex marked the end of the Grampian deformation in this part of Ireland (see also Dewey \& Mange 1999).

\section{Midland Valley Terrane}

Faunal (e.g. Williams 1962; Ingham 1978; Rushton \& Tripp 1979; Ingham et al. 1986) and palaeomagnetic (Torsvik et al. 1996) evidence consistently show that the Midland Valley Terrane lay close to the low latitude Laurentian margin throughout the Ordovician. The Midland Valley Terrane extends along strike into the Notre Dame Subzone in Newfoundland (e.g. Willams et al. 1995) and includes the South Mayo-Loch Nafooey (Zone 2 of Ryan \& Dewy 1991) and Midland Valley-Tyrone Sub-terranes (Bluck et al. 1992). 


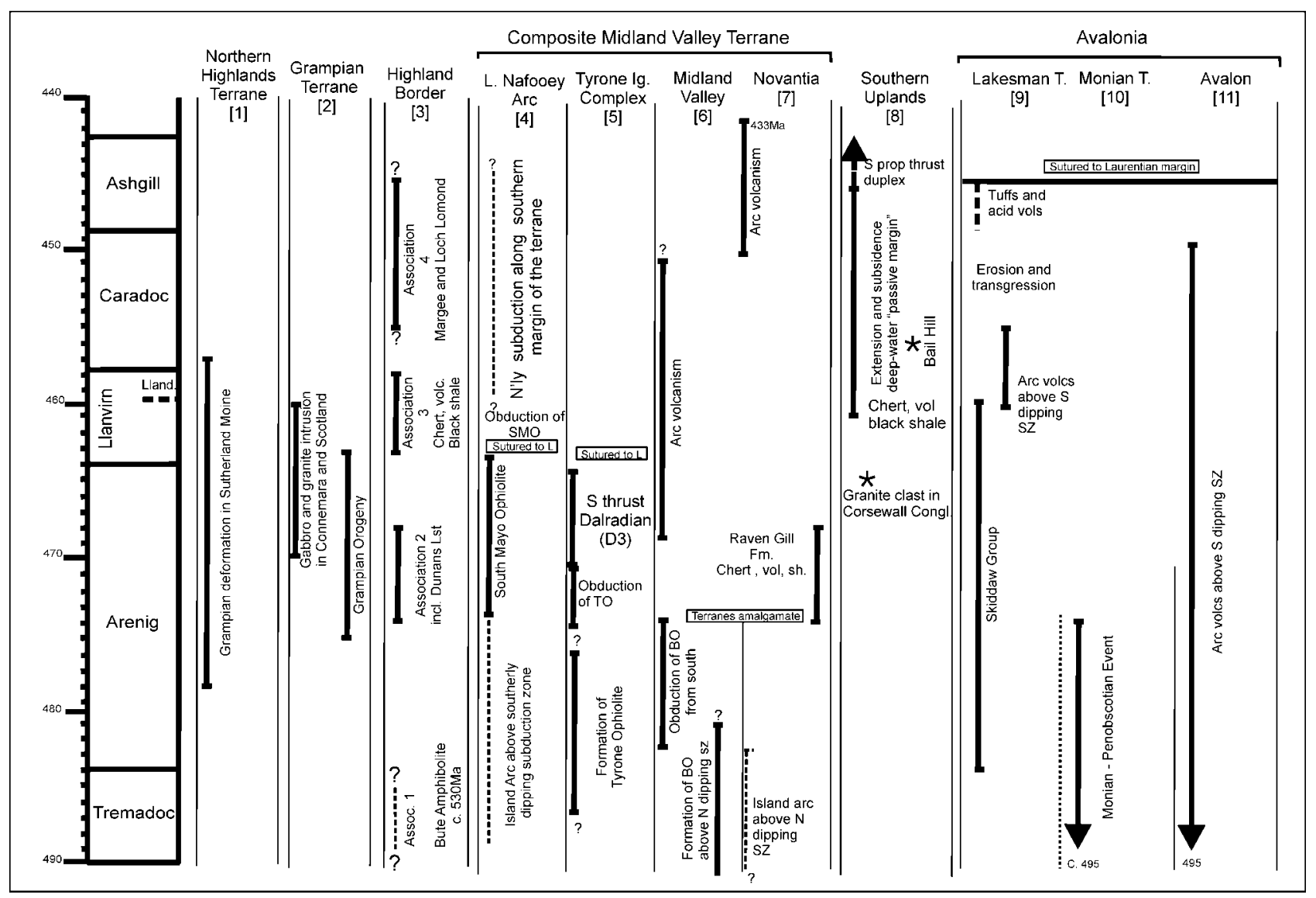

Fig. 2. Tectonostratigraphical range chart showing geological events in the terranes described in the text. Data have been synthesized from the numbered publications as follows: 1, Dempster (1985); 2, Soper et al. (1999); 3, Ingham et al. (1986), Curry et al. (1984), Dempster \& Bluck (1991); 4, Dewey \& Ryan (1990), Ryan \& Dewey (1991); 5, Hutton et al. (1985), Alsop \& Hutton (1993), Flowerdew (1999); 6, Armstrong et al. (1999), Kelley \& Bluck (1989, 1990); 7, Armstrong \& Owen (2000), Haughton (1988), Haughton \& Halliday (1991); 8, Kelley \& Bluck (1989), Armstrong et al. (1996), Scrutton et al. (1998), Phillips et al. (1999a). The age of the Bail Hill Volcanic group has been recalculated from the data in Harris et al. (1965) using the decay constants in Steiger \& Jäger (1977); 9, Cooper et al. (1993), Hughes \& Kokelaar (1993). The age of the Borrowdale Volcanic Group is mostly Caradoc, errors on radiometric dates extend the lower age range into the Llanvirn (see also Cooper et al. 1993); 10, Teitzsch-Tyler (1996); 11, Allen (1982), Hughes \& Kokelaar (1993). The chronostratigraphy is from Fortey et al. (1995) with the series boundaries calibrated as closely as possible to the chronometric timescale (Fortey et al. 2000).

The Midland Valley Terrane is a composite terrane extending south from the Highland Boundary and includes a southward extension now concealed beneath the northern part of the Southern Uplands (Upton et al. 1983; Davidson et al. 1984; Hall et al. 1984; Armstrong \& Owen 2000). This terrane may have extended even further to the south prior to the Siluro-Devonian tectonic excision of blocks along major strike-slip faults (see below). Bluck et al. (1992) considered the Midland Valley Terrane to have a complex metamorphic basement possibly including Archaean and later Precambrian rocks with dismembered ophiolites of Cambrian and Ordovician ages and concluded that it was the site of an Ordovician arc driven by northward subduction of the Iapetus Ocean. Ordovician cover successions have therefore been interpreted as having developed in back-arc (Highland Border, South Mayo Trough) and fore-arc (Girvan, South Mayo Trough) settings. Magmatic activity in the Midland Valley Arc can be determined from northerly-derived granitic clasts in conglomerates in the Girvan Ordovician cover sequence which have ages ranging from $593 \pm 28 \mathrm{Ma}$ to $451 \pm 8 \mathrm{Ma}$ (Bluck $1983,1984)$. The youngest dates are provided by clasts that are not much older than the conglomerate in which they occur, reflecting the rapid uplift and erosion of this arc.

Kelley \& Bluck (1989) inferred a source at for least some of the detritus in the Caradoc rocks of the Northern Belt of the Southern Uplands, including mica schist, as lying in a cooling metamorphic block lying to the north. They reported ages of detrital micas in the range 502-458 Ma (i.e. late Precambrian to earliest Caradoc). Muscovites in clasts of schist from the Ashgill Shinnel Formation in Scaur Water and the Llandovery conglomerate at Craigenputtock also provided an ${ }^{40} \mathrm{Ar} /{ }^{39} \mathrm{Ar}$ age of $447 \pm 8 \mathrm{Ma}$ and a $\mathrm{Rb}-\mathrm{Sr}$ age of $463 \pm 5 \mathrm{Ma}$ respectively (Kelley \& Bluck 1990). Hutchison \& Oliver (1998) contended that this metamorphic detritus was derived from the Grampian Terrane based upon geochemical characterization of associated Barrovian zone garnets. Re-evaluation of the mica age data now suggest a mean age close to $480 \mathrm{Ma}$, significantly older than the 460-440 interval of rapid cooling in the Dalradian (Bluck, in press). We follow Stone \& Evans (1999) (Fig. 1) who also considered the Hutchison \& Oliver hypothesis unlikely as the $\varepsilon_{\mathrm{Nd}}$ and $\mathrm{Sm} / \mathrm{Nd}$ values for Kirkcolm greywackes lay at the extreme end of values for the Argyll 


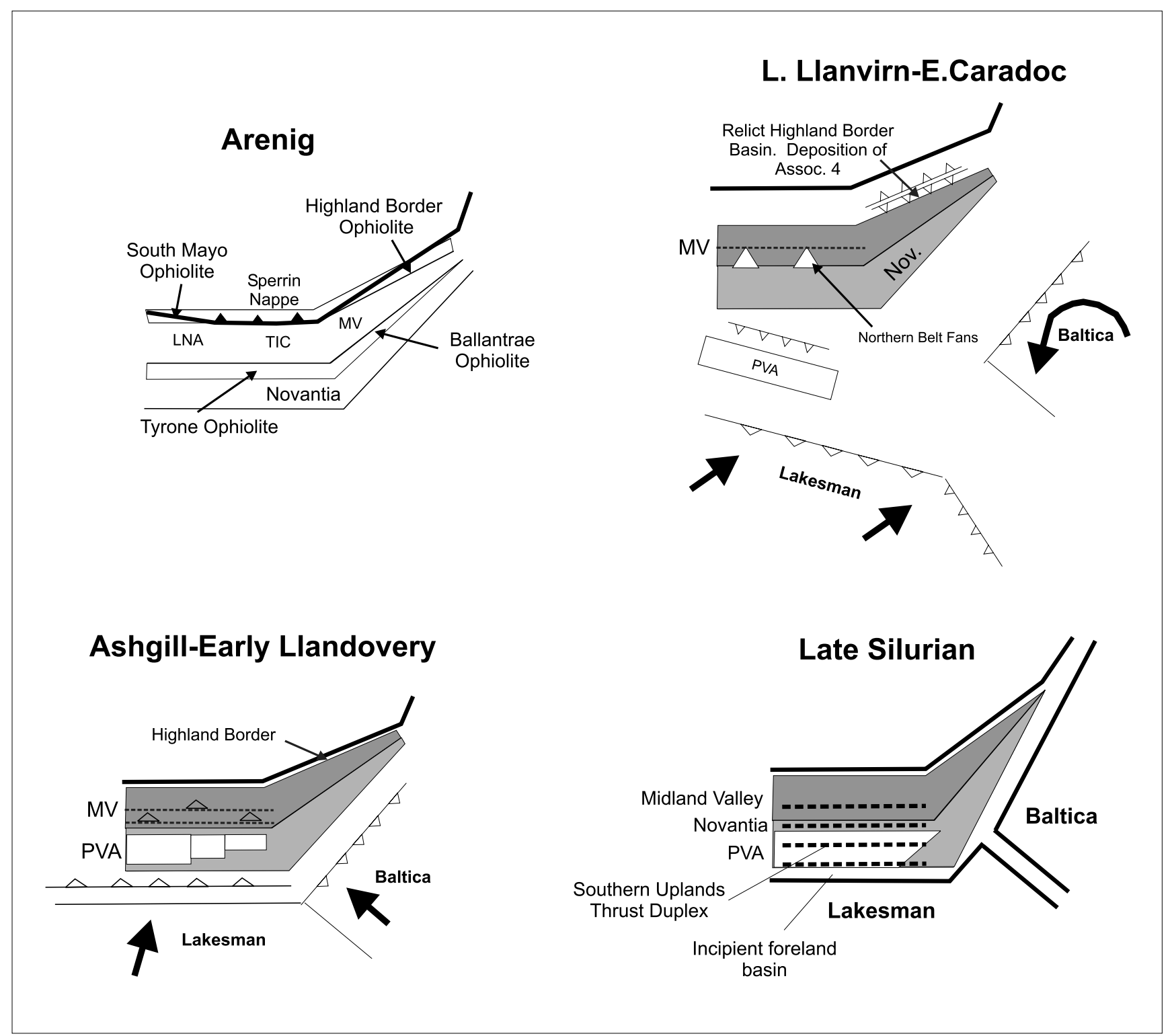

Fig. 3. Conceptual maps derived from the correlation chart (Fig. 2), recording the chronological sequence of terrane amalgamation events during the Caledonian Orogeny. Abbreviations: LNA, Loch Nafooey Arc; MV, Midland Valley; PVA, Grange, Popelogan-Victoria Arc-Grangegeeth terrane; SUP, Southern Uplands allochthon; TIC, Tyrone Igneous Complex.

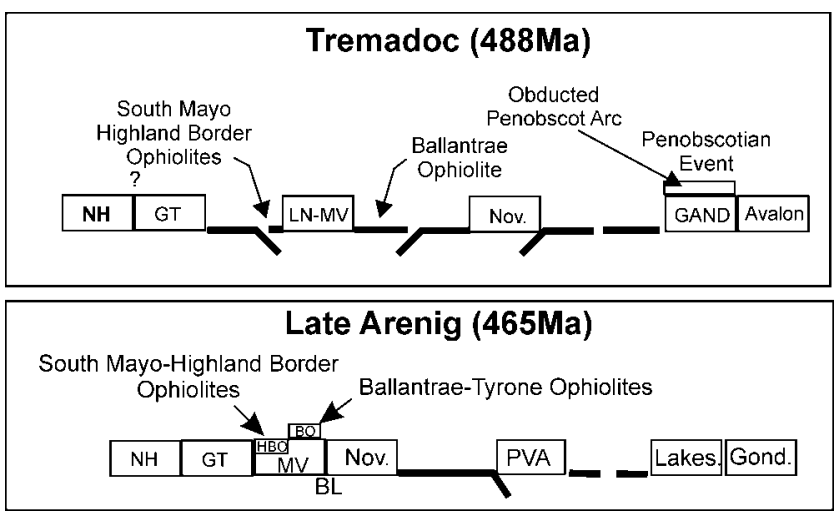

Fig. 4. Orogenic hypotheses derived from maps in Figure 3 illustrating relative positions of terranes up to the Grampian Orogeny (see insert on Fig. 1 for abbreviations).
Group alone. We also note that a $465 \pm 2.5 \mathrm{Ma}$ age for detrital garnet in the Southern Uplands (Oliver et al. 2000) lies within 5 million years of the onset of deposition within the Northern Belt of the Southern Uplands. To yield this material the Grampian Terrane would have had to be eroded to a depth of c. $20 \mathrm{~km}$ during this brief interval of time (Bluck pers. comm. 2000) and the sedimentary detritus then transported across an open oceanic Highland Border Basin containing a ridge and trench systems (see below) and an active Midland Valley Arc. Kelley \& Bluck (1989) also noted that the same source provided a substantial volume of volcanic and plutonic detritus derived from a magmatic arc, including large hornblendebearing granite clasts in the lower Caradoc Corsewall Conglomerate dated as c. $465 \mathrm{Ma}$ and containing xenoliths of garnet-mica schist and staurolite schist (Longman 1980). It appears most likely that the metamorphic detritus within the 

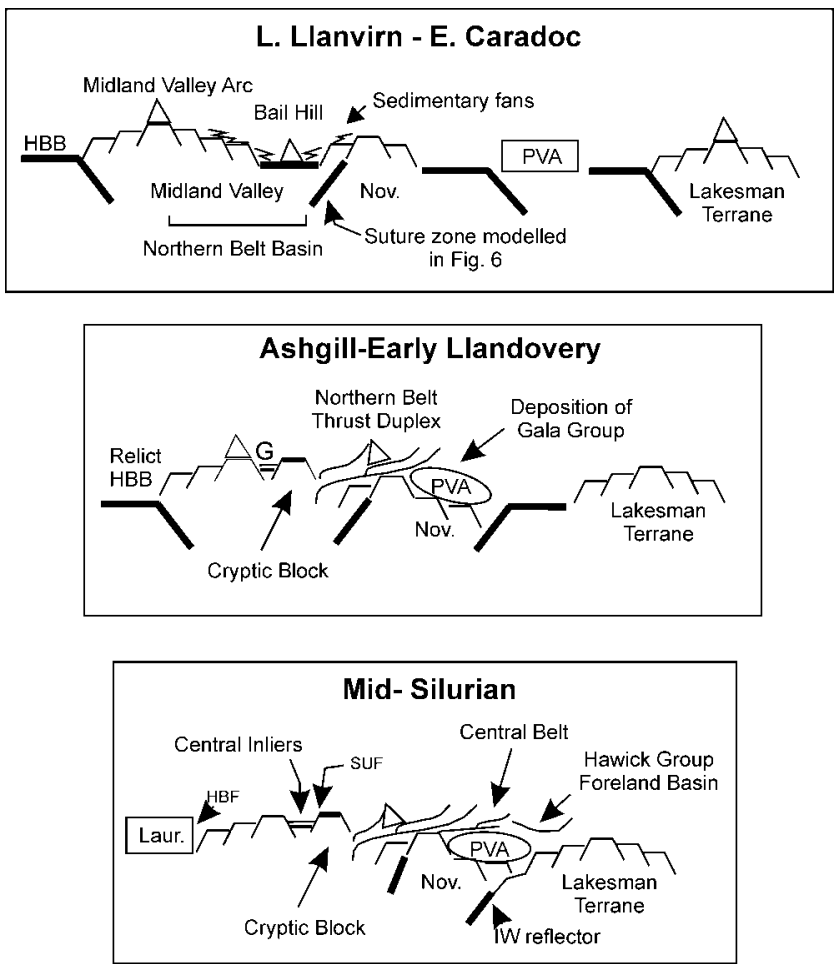

Fig. 5. Orogenic hypotheses derived from maps in Figure 3 illustrating relative positions of terranes from the late Arenig to early Devonian (see insert on Fig. 1 for abbreviations; G, Girvan). The Cryptic Block is a distal part of the Midland Valley Terrane that acted as a source to basins north and south of the Southern Upland Fault.

Midland Valley and Southern Uplands was locally derived from the Midland Valley Terrane.

Significantly, mid-Ordovician limestone clasts in southerly derived conglomerates in the Lower Old Red Sandstone (LORS) basins of the Midland Valley and in northerly derived Ordovician conglomerates in the Northern Belt of the Southern Uplands show that the southern margin of the Midland Valley Terrane had a cover of mid-Ordovician outer shelf limestone. This can be correlated with the Stinchar Limestone at Girvan, but was of a deeper water facies (Armstrong et al. 2000; Armstrong \& Owen 2000). Renewed arc magmatism in the Ashgill, in that part of the Midland Valley now hidden south of the present Southern Upland Fault, is indicated by high CAI (conodont alteration index) values of the conodonts in limestone clasts in the LORS (Armstrong \& Owen 2000) and possibly the $\mathrm{Rb}-\mathrm{Sr}$ age of $443.1 \pm 6.4$ obtained by Haughton \& Halliday (1991) for a southerly derived granite clast in the Old Red Sandstone of the Strathmore basin.

\section{Novantia}

In Newfoundland the Annieopsquotch Accretionary Tract lies between the Laurentian margin and Red Indian Line (van Staal et al. 1998) (Fig. 8). This tract comprises a early Arenig MORB-like ophiolite (Dunning 1987), 484 473 Ma island arc volcanic rocks (Buchans Group) and an eastward-directed thrust wedge tentatively correlated with the Northern Belt of the Southern Uplands by van Staal et al. (1998, p. 221). No comparable arc terrane has yet been described in Scotland, though an arc ('Cockburnland' of some authors) lay to the
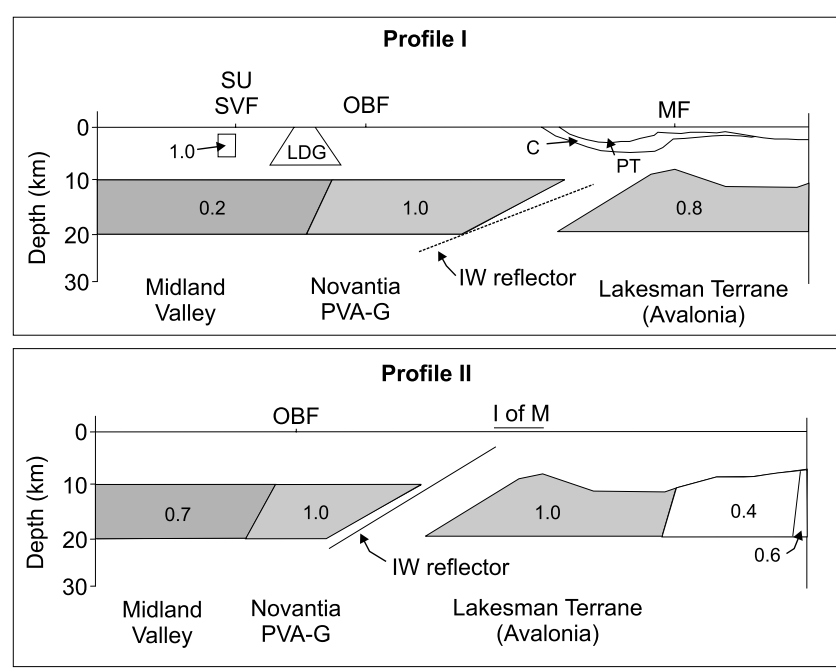

Fig. 6. Terranes recognized herein on the preferred geophysical models used to explain the magnetic structure of the crust along Profiles I and II in Figure 1 (redrawn after Kimbell \& Stone 1995, figs 3 \& 4). Shaded blocks are magnetic, with magnetizations in $\mathrm{A} / \mathrm{m}$ labelled the central part of the models. Abbreviations: SVF, Stinchar Valley Fault; LDG, Loch Doon Granite; CFG, Cairnsmore of Fleet granite; MF, Maryport Fault; PT, Permo-Triassic of the Solway Basin; C, Carboniferous of the Solway Basin; OBF, Orlock Bridge Fault; IofM, Isle of Man; IW, reflectivity boundary traditionally assumed to identify the Iapetus Suture (e.g. Brewer et al. 1983; Hall et al. 1984; Klemperer \& Matthews 1987).

south of the Southern Uplands and provided the source for the Caradoc, southerly-derived quartz and andesite-bearing greywackes of the Portpatrick Formation (Murphy \& Hutton 1986; Morris 1987; Kelling et al. 1987; Stone et al. 1987). These greywackes contain fresh volcanic detritus of Cambrian age (Kelley \& Bluck 1989) with isotopic compositions consistent with a source in a tholeiitic to calc-alkaline arc or back-arc assemblage founded on continental crust (Evans et al. 1991). Perspicaciously, van Staal et al. (1998, p. 228) suggested that the unroofing of the Popelogan-Victoria Arc (see below), following its collision with the active Laurentian margin, may have been the source of the southerly-derived greywackes in the Southern Uplands.

Kimbell \& Stone (1995, fig. 3b) (Figs 1 \& 6) modelled a marked change in the magnetic properties in the basement beneath the Southern Uplands, beneath the surface expression of the Orlock Bridge Fault and Moniaive Shear Zone. Stone et al. (1997) recognized this block as a potential source of geochemically distinct high-level granite plutons, and suggested that it may have rifted from Avalonia to supply the arc detritus northwards into the Southern Uplands basin. Here we name this terrane Novantia, after the Novantae a tribe who inhabited the south-western part of Scotland when the area was invaded by the Romans (e.g. Scott 1966).

The Arenig rocks within the Leadhills Imbricate Zone in the Northern Belt of the Southern Uplands may hold important clues as to the early Ordovician setting of Novantia. Armstrong et al. (1999) showed that early to mid-Arenig cherts of the Raven Gill Formation from the Leadhills Imbricate Zone in the Northern Belt have a continental margin Rare Earth Element geochemistry. Arenig conodonts from interbedded mudstones (see Armstrong et al. 1990) are typical of the Oepikodus Biofacies, defined by the dominance of $O$. evae and 
subordinate Periodon, Drepanoistodus, Protopanderodus and Oistodus (Bagnoli \& Stouge 1996). This is a deep-water assemblage typical of slope deposits of palaeocontinental margins (Stouge \& Bagnoli 1990) which accords well with the chert geochemistry. In contrast, Phillips et al. (1995a) interpreted the MORB-like geochemistry of basalts included in the Raven Gill Formation along the Leadhills Line as island arc tholeiites and volcanic island basalts influenced by an underlying slab of ocean crust. However, the available dates for the Leadhills volcanics (490 $\pm 14 \mathrm{Ma}$, Thirlwall in McKerrow et al. 1985) indicate that they are older than the chert and conodontbearing sediments, recording a late Cambrian to early Arenig island setting for at least part of Novantia (Fig. 4). Northward subduction beneath Novantia during that time would be consistent with the northerly subduction polarity beneath the Ballantrae Complex (Stone \& Smellie 1990; Bluck 1992; Armstrong et al. 1999; compare Smellie \& Stone 1992) which we propose lay to the north (Figs $3 \& 4$ ). We propose that the collision of Novantia with the Midland Valley during the Arenig was the cause of Ballantrae-Tyrone obduction. This amalgamated terrane then collided with the Laurentian margin and was the cause of the Grampian Orogeny.

\section{Southern Uplands}

Apart from the middle Arenig (and possibly older) rocks exposed in the Leadhills Imbricate Zone there is no unequivocal evidence for rocks older than the late Llanvirn in the Southern Uplands. A sponge, Konyrium varium Nazarov \& Popov, identified from cherts in the Leadhills Imbricate Zone by Danelian et al. (1999) has also been recorded in North America from older levels, but its type horizon in Kazakhstan is late Llanvirn in age; comparable with the other biostratigraphical evidence for the Northern Belt. Thus on present evidence it seems that deposition in the Northern Belt Basin began in the late Llanvirn long after the deposition of the mid-Arenig rocks of the Leadhills Imbricate Zone.

Armstrong et al. (1996) provided a review and reinterpretation of the geology of the Northern Belt Basin, the oldest part of the Southern Uplands. This included a reinterpretation of the upper Llanvirn to lower Caradoc volcanic rocks as attenuated within plate rather than ocean island or MORB. Volcanism was short-lived (Armstrong et al. 1998) and cherts associated with the lavas and tuffs have continental margin REE profiles (Owen et al. 1999), confirming the Northern Belt succession is best explained as having been deposited on an extending and subsiding continental margin (Armstrong et al. 1996). That margin is here interpreted as being the newly amalgamated Midland Valley Terrane. The down-slope transport of kilbuchophyllid corals into the Northern Belt Basin suggests an original site of deposition further to the west during the mid-Caradoc, the only authochthonous record of the corals being at Pomeroy, northern Ireland (Scrutton et al. 1998).

The lower Caradoc Bail Hill Volcanic Group, has a mean age of $456 \mathrm{Ma}$, and forms an integral part of the Northern Belt of the Southern Uplands (Phillips et al. 1999). It is a geochemically distinctive volcanic edifice comprising a heterogeneous succession of submarine lavas, volcaniclastic and intrusive rocks (Phillips et al. 1999) built on a foundation of lower Caradoc (gracilis Biozone) shales. The upper part of the complex includes volcaniclastic and lava units inter-bedded with continentally derived turbidites of the Kirkcolm For- mation. The chemistry of the Bail Hill Volcanic Group has been considered to be consistent with that of oceanic withinplate basalts or as part of an extending back-arc basin (Phillips et al. 1999). We interpret the Bail Hill volcanic rocks to have been part of a larger extensional domain across the Laurentian margin with the Northern Belt Basin as an extending marginal basin.

\section{Popelogan-Victoria Arc-Grangegeeth Terrane}

In Newfoundland the Popelogan-Victoria Arc lies to the south of the Red Indian Line. This Arenig to Caradoc arc complex, rifted from the Gondwana margin and drifted northwards between about 473 and $455 \mathrm{Ma}$, above a southward-dipping subduction zone (van Staal et al. 1991; van Staal 1994). It collided with the Summerfield Seamount and the Laurentian margin in the Caradoc (van Staal et al. 1991, 1998; Prave et al. 2000). Van Staal et al. (1998; see also Cocks et al. 1997) considered that the Grangegeeth Terrane of eastern Ireland (Romano 1980; Winchester \& van Staal 1994) may be a displaced part of the Popelogan-Victoria Arc. The lower Llanvirn rocks at Grangeeth contain high latitude province graptolites whilst lower Caradoc sediments, interbedded with volcanic rocks, contain a dominantly Scoto-Appalachian shelly fauna (Harper \& Parkes 1989; Owen et al. 1992; Romano \& Owen 1993). A similar change in faunal provinciality is also shown by the Popelogan-Victoria Arc in Canada and northern Appalachians, ascribed to northward drift during the Ordovician (Williams et al. 1992). It is likely that allochthonous masses of arc-related basaltic rocks within the upper Caradoc Moffat Shale Group in the Gabsnout Burn area of the Southern Uplands (Barnes et al. 1995) and southerly-derived volcanic arc detritus in the Gala Group were derived from a single source the Popelogan-Victoria Arc-Grangegeeth Terrane.

Anderson \& Oliver (1996) reported metabasaltic xenoliths from a lamprophyre dyke in the Central Belt of the Longford Down in Ireland and interpreted the source as lying in the underplated Lakesman Terrane beneath the IW reflector, a reflective line assumed to identify the Iapetus Suture (e.g. Brewer et al. 1983; Hall et al. 1984) (Fig. 6). This interpretation was largely based on similarity in major and trace element chemistry between a xenolith and selected Borrowdale Volcanic Group basalts. The xenoliths are metamorphosed to prehnite-pumpellyite facies indicative of 2-8 kbar and temperatures of $300-350^{\circ} \mathrm{C}$. The IW reflector lies at $21 \mathrm{~km}$ below the present day surface in the WINCH 2 cross section (England pers. comm. in Anderson \& Oliver 1996). The present day surface comprises Gala Group greywackes that exceptionally reach the same metamorphic grade, but are more typically diagenetic and anchizone grade (Stone 1995). Assuming a typical grade of anchizone then the deepest parts of the Central Belt have never exceeded $200^{\circ} \mathrm{C}$ (Merriman \& Frey 1999). Assuming an average continental geothermal gradient of $30^{\circ} \mathrm{C} \mathrm{km}^{-1}$ then the Gala Group has been buried to a maximum $6.6 \mathrm{~km}$ and the xenoliths to $11.6 \mathrm{~km}$. However, given that the xenoliths were derived from a major collision zone the geothermal gradient may have been significantly higher (Schubert et al. 1975) and these depths represent the maximum possible burial. Even if significant amounts of the Gala Group had been removed prior to the metamorphism of the xenoliths (hypothesis of Anderson \& Oliver 1996) temperatures at the IW reflector would have reached a minimum of $630^{\circ} \mathrm{C}$. A more parsimonious hypothesis is that the xenoliths 
were derived from the Popelogan-Victoria-Grangeeth Arc above the IW reflector and because this source had a similar setting and history to the Lakesman Terrane it is likely to have contained rocks with a similar chemistry.

\section{Terranes of Avalonia}

The sector of Avalonia represented in the British Isles had an early Palaeozoic history that is far more complex than the early plate tectonic and magmatic models suggested. The main terranes that can be recognized (Bluck et al. 1992) are, from north to south: the Leinster-Lakesman, the Monian terrane(s) and the Avalon Terrane (including the Welsh Basin). The original spatial relationships between the Irish, northern English and Welsh basins are far from clear (Kokelaar 1988; Owen \& Parkes 2000). Van Staal et al. (1996, 1998, p. 212) suggested that the Rosslare and Coedana complexes within the Monian terrane(s) may be correlated with the Ganderian basement seen in the Appalachians. They noted that the timing of the juxtaposition of Ganderia with what was to later become Avalonia on the Gondwanan margin is not clear but that the evidence from Britain suggested that it had taken place by the late Cambrian. After this, these terranes behaved as a single unit (which they termed Avalon), albeit with considerable internal strike-slip modification. Cocks et al. (1997) reviewed the margins of Avalonia and van Staal et al. (1998) suggested that the early Ordovician obduction of the Penobscot Arc onto Ganderia may also be reflected in the early Ordovician deformation which affected the Monian terranes (see also Teitzsch-Tyler 1996). This deformation was followed by southward subduction beneath Ganderia and the rifting off and rapid drift northwards of the Popelogan-Victoria ArcGrangegeeth terrane (Figs 3 \& 4); the early magmatic activity possibly also being reflected in the late Tremadoc-early Arenig arc development in the Welsh Basin. Further rifting at the Gondwana margin during the late Arenig-early Llanvirn, with magmatism in the Welsh basin, saw the separation of Avalon (Ganderia-Avalonia) and the development of the Rheic Ocean (Cocks et al. 1997; van Staal et al. 1998). The eruption of the tholeiitic Eycott Volcanic Group and the calc-alkaline Borrowdale Volcanic Group arc systems during the early Caradoc in the North of England (Cooper et al. 1993, fig. 2) occurred above a subduction zone. This may have resulted from the late Ordovician closure of the Tornquist Sea between Avalonia and Baltica (Cocks et al. 1997; van Staal et al. 1998, p. 230). The westward extension of this subduction zone also resulted in the northward drift of Avalonia towards the terranes of the Laurentian margin.

\section{Revised Caledonian model}

\section{Early Ordovician collisions in the northern Iapetus Ocean}

During the Tremadoc and early Arenig, the Loch Nafooey Arc, and by inference the Midland Valley Arc and its equivalent in Tyrone (Fig. 4), lay to the south of the developing South Mayo Ophiolite above a southerly dipping subduction zone (Ryan \& Dewey 1991, fig. 2; but see Johnson \& Phillips 1995 for an alternative interpretation of subduction polarity). This arc complex collided with the Laurentian margin in the Arenig, deforming the Dalradian Supergroup (Soper et al. 1999; Dewey \& Mange 1999) during what is widely termed the Grampian Orogeny. The overlapping stratigraphical ages for

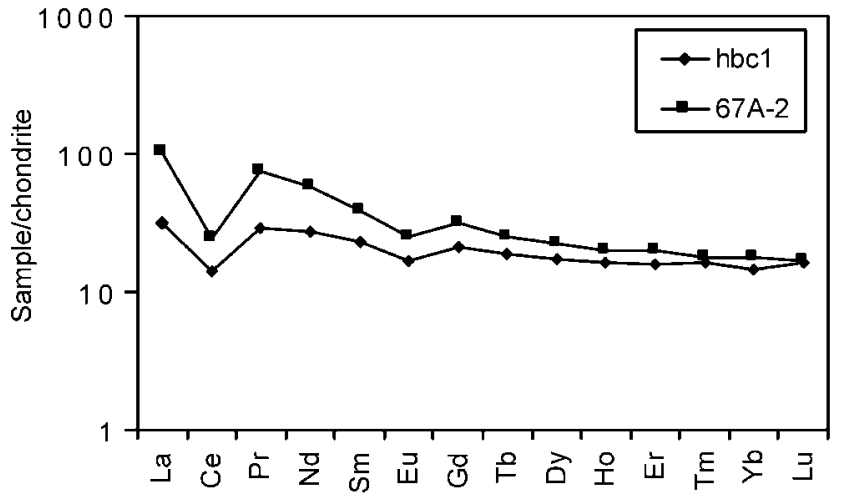

Fig. 7. Chondrite-normalized REE abundance plot for Highland Border Complex chert. Sample hbcl is from Craigeven Bay (GR. NO 891875 ) and was processed and analysed as outlined in Owen et al. (1999). Sample 67A-2 is from Murray et al. (1992) illustrating a typical REE abundance profile from chert at the Pacific Rise.

the various suture ophiolites constrain this event at about $474 \mathrm{Ma}$.

We propose that at the same time, Novantia collided with the Midland Valley Terrane, causing the obduction of the Ballantrae and Tyrone ophiolites (Fig. 4). Given the complexity of the basin which is reflected in the Ballantrae ophiolite (e.g. Armstrong et al. 1999 and references therein), elements may also have been accreted onto the northern edge of Novantia leading to crustal thickening, deformation and magmatism therein. The suture lies in the lower crust beneath the later line of the Orlock Bridge Fault and Moniaive Shear Zone though these are much later structures. The ophiolites would therefore have originally extended northwards from this line and the middle to upper Llanvirn alluvial to shallow marine sedimentary rocks of the Girvan area (which are the cover on the Ballantrae Ophiolite) represent part of the overlap succession of the suture zone. Complete sedimentary linkage between the Midland Valley and Novantia had occurred by the latest Llanvirn-earliest Caradoc with the development of the limestone platform represented by the Stinchar Limestone at Girvan and its distal (southern) equivalents now only seen as clasts in younger conglomerates (Armstrong \& Owen 2000).

\section{Post-Arenig basins on the composite Midland Valley Terrane}

Following the Arenig collision event, regional extension, possibly across the entire Laurentian margin, caused subsidence and the accumulation of locally derived, alluvial fan to shallow marine Kirkland and Benan conglomerates (Ince 1984) and associated Barr Group marine sediments. We propose that as part of this extensional event, the amalgamated Midland Valley Terrane rifted from the Laurentian margin to form the Highland Border marginal basin. A chert of probable Llanvirn or Caradoc age from the Highland Border Complex at Craigeven Bay near Stonehaven (Fortey et al. 2000, fig. 25) (Fig. 7) has a REE profile and pronounced cerium anomaly characteristic of a ridge setting, attesting to the development of an ocean basin. However, such a basin probably never attained any great width and we argue that subduction occurred on both its northern and southern margins (Fig. 3), producing arc rocks in the northern part of the amalgamated Midland Valley Terrane and granite plutons and uplift in the Grampian 


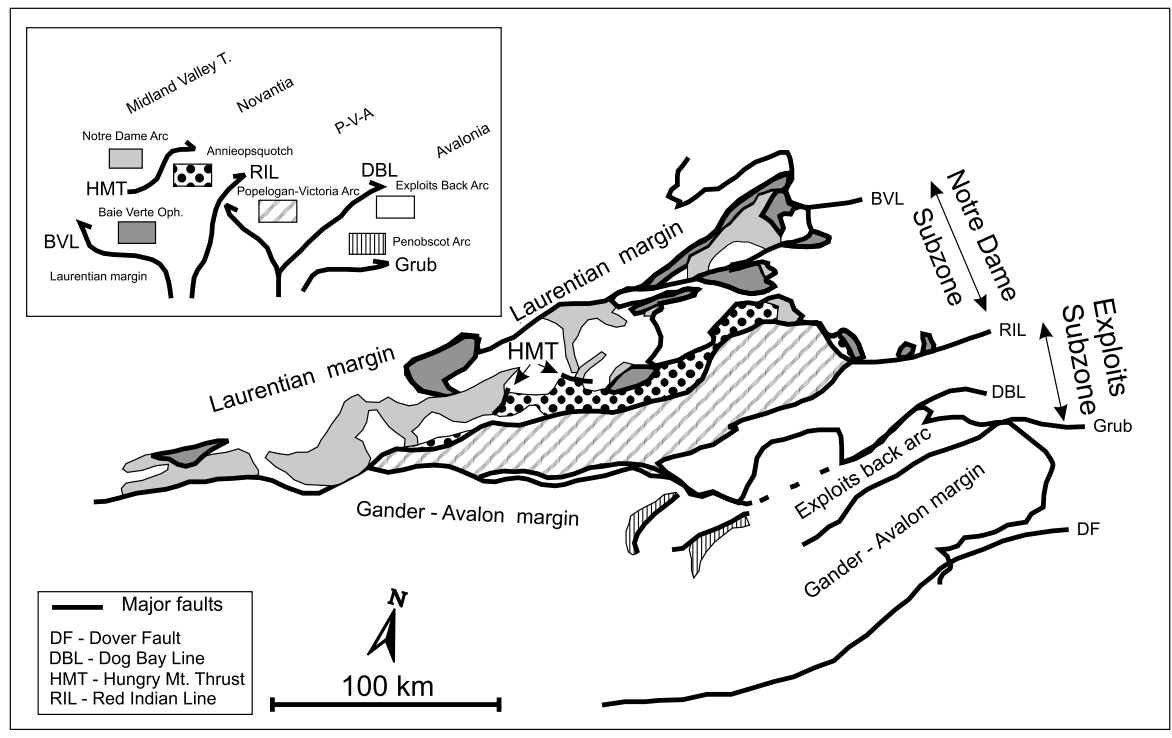

Fig. 8. Simplified terrane map of the Central Mobile Belt of Newfoundland (modified from Colman-Sadd et al. 1992; van Staal et al. 1998). Silurian and Devonian plutons have been removed. The insert represents a summary of the structural relationships between the various tectonic elements and our proposed correlation with the Caledonian terranes in Britain. Van Staal et al. (1998) considered the Notre Dame Subzone to have been progressively emplaced over the Grenville margin during the Tremadoc-Llanvirn. The southern edge of the Midland Valley Terrane, Novantia and the Popelogan-Victoria Arc lie beneath the Southern Uplands Allochthon in Britain.
Terrane. Granite clasts in Ordovician conglomerates in the Girvan cover sequence indicate that an arc was active within the Midland Valley Terrane to at least $451 \pm 8 \mathrm{Ma}$ (Bluck 1985). In the Southern Highlands, major uplift occurred between 460-440 Ma (Dempster 1985; see also Dempster et al. 1995 for the NE Dalradian), suggesting the effects of northward subduction may have continued into the late Ordovicianearliest Silurian before a plutonic hiatus between 440-415 Ma (Dempster 1985). The presence of a subduction zone beneath the Southern Highlands may account for the absence of Dalradian detritus in the Highland Border Complex (e.g. see Dempster \& Bluck 1989). The Highland Border basin was the site of deposition of a sedimentary succession of mid-Arenig (Association 2) and Llanvirn (?Llandeilian) to the midCaradoc or even Ashgill (Associations 3 and 4; Curry et al. 1984) although this has been largely dismembered by later strike slip faulting and is only seen as isolated slivers along the Highland Boundary Fault zone (see summary in Fortey et al. 2000). The younger Ordovician succession here is seen as having been deposited in a fore-arc setting along the northern margin of the Midland Valley Terrane with the Girvan succession having accumulated in a back-arc setting (Fig. 5).

In the southern Iapetus Ocean, early Ordovician southward subduction resulted in the rifting from Gondwana of the Popelogan-Victoria Arc-Grangegeeth Arc and ultimately, in the late Arenig-early Llanvirn, of Avalon itself and their rapid drift northwards (van Staal et al. 1998) (Figs 4 \& 5), resulting from the opening of the Rheic Ocean. Late Llanvirn to early Caradoc slab-pull on the southern edge of the amalgamated Midland Valley Terrane led to rapid subsidence, basaltic magmatism (Armstrong et al. 1998) and the initiation of the Northern Belt Basin. Finally incipient rifting resulted in the development of the Bail Hill Igneous Complex (Fig. 5). We therefore argue that the Northern Belt Basin is founded on attenuated Midland Valley crust. The early fill of this basin included olistostromes, detritus from the Arenig ophiolite, Arenig granite clasts and clasts from the metamorphic basement into which they were intruded. Southerly-derived Cambrian andesitic detritus (Kelley \& Bluck 1989) was periodically introduced from the uplifted parts of Novantia.

Oblique collision of the Popelogan-Victoria ArcGrangegeeth terrane with the Laurentian margin during the latest Caradoc-Ashgill initiated thrusting in the Northern Belt and may have been responsible for translating the Northern Belt north eastwards. The presence of deep water limestone clasts in the Tweeddale Member of the Shinnel Formation (Armstrong 1997) derived from the north (Evans et al. 1991; Armstrong et al. 1996) places a maximum age on the initiation of the deformation in the Northern Belt as mid-Ashgill. These limestone blocks (the Wrae Limestone) were derived from a portion of the Midland Valley (the Cryptic Block in Fig. 5) which was strike-slip excised during the early Devonian (see below).

A short period of northerly subduction related to the northwards drift of the Leinster-Lakesman Terrane resulted in arc volcanism of Ashgill age in the Midland Valley Terrane. This volcanism would account for the Ashgill thermal event indicated by conodonts in the limestone clasts derived from the Cryptic Block (CAI 5-6 compared to the much lower thermal alteration (CAI 1.5-2) in equivalent limestones at Girvan (Armstrong \& Owen 2000)) and the southerly derived granite clast dated as $443 \pm 6.4$ Ma by Haughton \& Halliday (1991) in the ORS of the Strathmore Basin. The northward dip of the IW reflector (Fig. 6), traditionally regarded as the Iapetus Suture (e.g. Kimbell \& Stone 1995), and the dominantly orthogonal pattern characterizing the later phases of deformation in the Southern Uplands (Barnes et al. 1989) is also be attributed to northwards subduction.

\section{Closure of post-Arenig basins}

The southerly prograding Southern Uplands thrust duplex formed the hinterland to a foreland basin that eventually extended into Avalonia. Illite crystallinity data across the Northern Belt and parts of the Central Belt indicate an inverted burial metamorphism, with grade increasing into sequentially younger tracts. This pattern of regional metamorphism is consistent with its development during thrust imbrication where younger strata were buried beneath older thrusts slices (Stone 1995). Oblique 'soft' collision of the LeinsterLakesman Terrane (Hutton 1987; Pickering et al. 1988), continued the southerly migration of the Southern Uplands duplex and by the Llandovery-Wenlock boundary had transformed 
the southern margin of the Laurentia into a major zone of sinistral transpression. An orthogonal collisional regime was re-established in the Southern Uplands by the Wenlock (Barnes et al. 1989; Rushton et al. 1996).

Sedimentary geochemistry indicates a fundamental switch in provenance in the mid-Gala Group (Barnes 1998; Williams et al. 1996; Barnes \& Stone 1999) from the intermittent volcanic provenance to a sediment source probably rich in heavy minerals. Hawick Group sandstone compositions are uniform, through distinct from the Gala Group, containing a matrix with a high carbonate content. Hawick and Riccarton group sandstones and those from the late Wenlock Windermere Supergroup in the Lake District are generally similar, consistent with a closely linked depositional system (Stone et al. 1999a, b; Barnes \& Stone 1999). The foreland basin also included ophiolitic detritus from the Scandian Orogen (McCaffrey \& Kneller 1996; Stone et al. 1999a).

The apparent structural continuity between the Midland Valley-Novantia suture (at depth) and the Moniaive Shear Zone indicates the Northern and Central belts of the Southern Uplands were stitched to the basement by the Wenlock (Phillips et al. 1995b).

A feature of all the Silurian Inliers of the Midland Valley is the importance of syn-sedimentary sinistral strike-slip during the Silurian (Soper et al. 1992; Smith 1995; Phillips et al. 1998). An indication of this is the accumulation of more than $1.8 \mathrm{~km}$ of turbidites in the Pentland Sub-basin during the Rhuddanian-Aeronian (cyphus to sedgwickii biozones) (Robertson 1989). Local deformation and uplift within the Silurian Inliers is contemporaneous with $\mathrm{D}_{3}$ sinistral strike-slip deformation within the Southern Uplands Terrane (earliest Wenlock, Barnes et al. 1989). Intrusive and ?extrusive igneous activity during the Wenlock within the Midland Valley and Grampian terranes (Watson 1984) and strike-slip reactivation along the Great Glen, Highland Border and Strathconan faults (Bluck 1985; Hutton \& McErlean 1991) may also be related to this phase of transcurrent shear.

By the early Ludlow the Cryptic Block was rejuvenated as a pop-up within this collision zone to provide a source of mid-Ordovician sediment to the Lanark and Strathmore basins (Armstrong \& Owen 2000). It is likely the present basement terrane geometry was established in this mid-Silurian transpressional event, with the northeasterly excision of the Cryptic Block in the latest Silurian to Early Devonian. We also regard the Ayr-Ochil-Sidlaw Ridge (Bluck 1985) as a volcanic chain forming in a transtensional regime during the late Silurian and a potential source for the late Silurian igneous detritus in the Crawton Group of the Strathmore Basin.

The Cheviot lavas are Emsian in age $(395 \pm 3.8 \mathrm{Ma}$, Thirlwall 1988) and lie on vertical and peneplained Wenlock greywackes. Essentially all Caledonian deformation had ceased by this time, though the major Caledonian lineaments such as the Southern Upland Fault may have been periodically reactivated during the Devonian and Carboniferous (Floyd 1994).

This scenario has important implications for the definition of the location of the Iapetus Suture. Traditionally this has been drawn between areas with Laurentian and Gondwana faunas; a definition which results in a Iapetus Suture that migrated spatially and temporally through the Ordovician (see also Williams et al. 1992). This is because of: (a) the southerly progradation of the Laurentian margin with time and (b) the northward drift, to lower latitudes, of terranes and the consequent change in their faunas. The Highland Boundary Fault defines the southern margin of Laurentia during the early Ordovician; south of this all terranes should be considered part of the Caledonian Mobile Belt. The Ballantrae Line as defined here (and its lower crustal equivalent) is a terrane boundary within the Midland Valley Terrane. If the Iapetus Suture is defined as the line between terranes of Gondwanan and Laurentian affinity then the affinity of Novantia becomes critical. The geophysical and igneous geochemical evidence suggests this has greater similarity with Avalon than the Midland Valley Terrane. If this is the case then the Ballantrae Line marks the surface expression of the Iapetus Suture and it is a mid-Arenig structure. The northern and southern edges of the remnants of the Popelogan-Victoria Arc-Grangegeeth Terrane mark the positions of later sutures (e.g. see Owen et al. 1992).

The ability to correlate terranes between Scotland and Newfoundland strengthens our model. However, perceived problems with this re-interpretation lie in the presence of two island arcs beneath the Southern Uplands, a zone little more than $150 \mathrm{~km}$ wide and, the inability to differentiate the arcs by geophysical means (Kimbell \& Stone 1995) (Fig. 6). We counter these criticisms: firstly, tectonic excision of parts of these arcs during subsequent oblique collisions may account for the space problems and coincidentally provide an origin for cryptic terranes in the northern North Sea basement. Secondly, both arcs were derived from the Gondwana margin during the early Ordovician and potentially have the same lower crustal physical properties.

\section{Conclusions}

The orogenic model developed herein allows the reconstruction of the history of the paratectonic Caledonides in Britain, much of which can be readily correlated into Newfoundland (Fig. 8) and the northern Appalachians. Crucial to understanding the complex sequence of terrane amalgamation events is the recognition of Novantia and the Popelogan-Victoria Arc-Grangegeeth terranes, now hidden beneath the Southern Uplands.

The Grampian Orogeny resulted from the accretion to Laurentia during the Arenig of two arc terranes, the Midland Valley (=Notre Dame Terrane in Newfoundland) and Novantia (=Annieopsquotch Terrane partim in Newfoundland). The suture lies along the line of the South Mayo-Highland Border ophiolites that were obducted onto the northern edge of the Midland Valley Terrane. The Tyrone and Ballantrae ophiolites mark a terrane boundary within the composite Midland Valley Terrane that is equivalent to the Hungry Mountain Thrust in Newfoundland (Fig. 8).

Following the Grampian Orogeny a period of extension across the Laurentian margin resulted in the opening of marginal basins, a response to slab pull-subduction beneath the advancing Popelogan-Victoria Arc-Grangegeeth and Lakesman arcs. The Late Ordovician to mid- Silurian was a period of further arc accretion. The first, the oblique collision of the Popelogan-Victoria-Grangegeeth Arc during the Ashgill, resulted in the initiation of the Southern Uplands thrust duplex. The second, the accretion of the Lakesman Arc (Avalonia) in the mid-Silurian, transformed the Laurentian margin into a major zone of sinistral transpression.

The accreted Popelogan-Victoria Arc-Grangegeeth Terrane is poorly exposed in the British and Irish sectors, largely obscured by the Southern Uplands thrust duplex-foreland 
basin, an apparent equivalent to parts of the Exploits Subzone in Newfoundland (Colman-Sadd et al. 1992; Williams et al. 1992). The IW reflector to the north of the Lakesman Terrane is equivalent to the Dog Bay Line in Newfoundland.

The Caledonian Orogeny in Britain resulted from the progressive oblique collision of island arcs from the Early Ordovician to mid-Silurian, with ophiolites marking major suture zones. Difficulties in reconciling the terrane templates of Britain and Newfoundland have resulted from the southward thrusting of the Southern Uplands over Novantia and the Popelogan-Victoria Arc-Grangegeeth terranes.

This paper largely arose as a result of work undertaken during the tenure of a NERC small grant (GR9/02834) which is gratefully acknowledged. B. J. Bluck, P. Stone, G. J. H. Oliver and G. Kelling kindly read and greatly improved earlier versions of this manuscript. C. J. Ottley, University of Durham analysed the Highland Border Complex chert by ICP-MS.

\section{References}

Allen, P.M. 1982. Lower Palaeozoic volcanism in Wales, the Welsh Borderland, Avon and Somerset. In: SutherLAND, D.S. (ed.) Igneous rocks of the British Isles. Wiley \& Son, Chichester, 65-91.

Alsop, G.I. \& Hutton, D.H.W. 1993. Major southeast-directed Caledonian thrusting and folding in the Dalradian rocks of mid-Ulster: implications for Caledonian tectonics and mid-crustal shear zones. Geological Magazine, 130, 233-244.

Anderson, T.B. \& Oliver, G.J.H. 1996. Xenoliths of Iapetus Suture mylonites in County Down lamprophyres. Journal of the Geological Society, London, 153, 403-407.

Armstrong, H.A. 1997. Conodonts from the Shinnel Formation, Southern Uplands, Scotland. Palaeontology, 40, 763-797.

Armstrong, H.A. \& Owen, A.W. 2000. Age and provenance of limestone clasts in LORS conglomerates: implications for the strike-slip accretion of the Midland Valley Terrane. In: Friend, P.F. \& Williams, B.P.J. (eds) New Perspectives on the Old Red Sandstone. Geological Society, London. Special Publications, 459-471.

Armstrong, H.A., Clarkson, E.N.K. \& Owen, A. 1990. A new Lower Ordovician conodont faunule from the Northern Belt of the Southern Uplands of Scotland. Scottish Journal of Geology, 26, 47-52.

Armstrong, H.A., Owen, A.W., Scrutton, C.T., Clarkson, E.N.K. \& TAYLOR, C.M. 1996. Evolution of the Northern Belt, Southern Uplands: implications for the Southern Uplands controversy. Journal of the Geological Society, London, 153, 197-205.

Armstrong, H.A., Rushton, A.W.A., Owen, A.W. \& Floyd, J.D. 1998. Biostratigraphy of the Currarie Formation on the northwestern edge of the Southern Uplands: implications for the cessation of basic volcanism. Scottish Journal of Geology, 34, 119-125.

Armstrong, H.A., Owen, A.W. \& Floyd, J.D. 1999. Rare Earth Element geochemistry of Arenig cherts from the Ballantrae Ophiolite and Leadhills Imbricate Zone, Southern Scotland-implications for origin and significance to the Caledonian Orogeny. Journal of the Geological Society, London, 156, 549-560.

Armstrong, H.A., Owen, A.W. \& Clarkson, E.N.K. 2000. Ordovician limestone clasts in the Lower Old Red Sandstone, Pentland Hills, southern Midland Valley Terrane. Scottish Journal of Geology, 36, 33-38.

Bagnoli, G. \& Stouge, S. 1996. Changes in conodont provincialism and biofacies during the lower Ordovician in Öland, Sweden. Palaeopelagos, 6, 19-29.

BARNES, R.P. 1998. Graphical display of sandstone geochemical data from the Southern Uplands, southern Scotland. British Geological Survey Technical Report.

Barnes, R.P., Lintern, B.C. \& Stone, P. 1989. Timing and regional implications of deformation in the Southern Uplands of Scotland. Journal of the Geological Society, London, 146, 905-908.

Barnes, R.P., Phillips, E.R. \& Merriman, R.J. 1995. Allochthonous Ordovician basaltic rocks of possible island arc affinity in the Southern Uplands, Southwest Scotland. In: HibBard, J.P., VAn StaAl, C.R. \& CAwood, P.A. (eds) Current perspectives in the Appalachian-Caledonian Orogen. Geological Association of Canada Special Papers, 41, 161-170.
BARnes, R.P. \& Stone, P. 1999. Trans-Iapetus contrasts in the geological development of southern Scotland (Laurentia) and the Lakesman Terrane (Avalonia). In: Woodcock, N.H., Quirk, D.G., Fitches, W.R. \& Barnes, R.P. (eds) In Sight of the Suture: the Palaeozoic geology of the Isle of Man in its Iapetus Ocean context. Geological Society, London. Special Publications, 160, 307-323.

BLuCK, B.J. 1978. Geology of a continental margin 1: The Ballantrae Complex. In: Bowes, D.R. \& LEAKE, B.E. (eds) Crustal evolution in northwestern Britain and adjacent regions. Geological Journal, Special Issues, 10, 151162.

BLuck, B.J. 1983. Role of the Midland Valley of Scotland in the Caledonian Orogeny. Transactions of the Royal Society of Edinburgh: Earth Sciences, 73, 119-136.

BLuCK, B.J. 1984. Pre-Carboniferous history of the Midland Valley of Scotland. Transactions of the Royal Society of Edinburgh: Earth Sciences, 75, 275295.

Bluck, B.J. 1985. The Scottish paratectonic Caledonides. Scottish Journal of Geology, 21, 437-464.

BLuCK, B.J. 1992. Terrane accretion in Western Scotland. In: LAwsON, J.D. \& WeEdon, D.S. (eds) Geological Excursions around Glasgow and Girvan. Geological Society of Glasgow, 20-49.

BLucK, B.J. 2000. Old Red Sandstone basins and alluvial systems of Midland Scotland. In: Friend, P.F. \& Williams, B.P.J. (eds) New Perspectives on the Old Red Sandstone. Geological Society, London. Special Publications, 417-437.

BLuck, B.J. 2000. Caledonian and related events in Scotland. Transactions of the Royal Society of Edinburgh: Earth Sciences, in press.

Bluck, B.J., Halliday, A.N., Aftalion, M. \& Macintyre, R.M. 1980. Age and origin of the Ballantrae ophiolite and its significance to the Caledonian orogeny and the Ordovician time scale. Geology, 8, 492-495.

Bluck, B.J., Gibbons, W.A. \& Ingham, J.K. 1992. Terranes. In: Cope, J.W.C., Imgham, A.J.K. \& Rawson, P.F. (eds) Atlas of Palaeogeography and Lithofacies. Geological Society of London, Memoirs, 13, 1-4.

Brewer, J.A., Matthews, D.H., Warner, M.R., Hall, J., Smythe, D.K. \& Whittington, R.J. 1983. BIRPS deep seismic reflection studies of the British Caledonides-the WINCH profile. Nature, 305, 206-210.

Church, W.R. \& Gayer, R.A. 1973. The Ballantrae ophiolite. Geological Magazine, 110, 497-510.

Cocks, L.R.M., McKerrow, W.S. \& van StaAl, C.R. 1997. The margins of Avalonia. Geological Magazine, 134, 627-636.

Colman-Sadd, S.P., Stone, P., Swinden, H.S. \& Barnes, R.P. 1992. Parallel geological development in the Dunnage Zone of Newfoundland and the Lower Palaeozoic terranes of southern Scotland: an assessment. Transactions of the Royal Society of Edinburgh: Earth Sciences, 83, 571-594.

Cooper, A.H., Millward, D., Johnson, E.W. \& Soper, N.J. 1993. The early Palaeozoic evolution of northwest England. Geological Magazine, 130, $711-724$.

Curry, G.B., Bluck, B.J., Burton, C.J., Ingham, J.K., Siveter, D. \& Williams, A. 1984. Age, evolution and tectonic history of the Highland Border Complex, Scotland. Transactions of the Royal Society of Edinburgh: Earth Sciences, 75, 113-133.

Danelian, T., Clarkson, E.N.K., Floyd, J.D. \& Armstrong, H.A. 1999. Radiolarian and conodont biostratigraphy of Arenig-Llanvirn chert sequences in the Southern Uplands of Scotland. British Geological Survey Technical Report, WA/99/65.

Davidson, K.A.S., Sola, M., Powell, D. \& Hall, J. 1984. Geophysical model for the Midland Valley of Scotland. Transactions of the Royal Society of Edinburgh: Earth Science, 75, 175-181.

Dempster, T.J. 1985. Uplift patterns and orogenic evolution in the Scottish Dalradian. Journal of the Geological Society, London, 142, 111-128.

Dempster, T.J. \& BLucK, B.J. 1989. The age and origin of boulders in the Highland Border Complex: constraints on terrane movements. Journal of the Geological Society, London, 146, 377-379.

Dempster, T.J. \& Bluck, B.J. 1991. Age and tectonic significance of the Bute amphibolite, Highland Border Complex, Scotland. Geological Magazine, 152, 77-80

Dempster, T.J., Hudson, N.F.C. \& Rogers, G. 1995. Metamorphism and cooling of the NE Dalradian. Journal of the Geological Society, London, 152, 383-390.

Dewey, J.F. \& Mange, M. 1999. Petrography of Ordovician and Silurian sediments in the western Irish Caledonides: tracers of a short-lived Ordovician continent-arc collision orogeny and the evolution of the Laurentian Appalachian-Caledonian margin. In: MaC Niocalll, C. \& Ryan, P.D. (eds) Continental Tectonics. Geological Society, London. Special Publications, 164, 55-107. 
Dewey, J.F. \& Ryan, P.D. 1990. The Ordovician evolution of the South Mayo Trough, Western Ireland. Tectonics, 9, 887-901.

DunNing, G.R. 1987. Geology of the Annieopsquotch Complex, southwest Newfoundland. Canadian Journal of Earth Sciences, 24, 1162-1174.

Evans, J.A., Stone, P. \& Floyd, J.D. 1991. Isotopic characteristics of Ordovician greywacke provenance in the Southern Uplands of Scotland. In: Morton, A.C., TodD, S.P. \& Haughton, P.D.W. (eds) Developments in Sedimentary Provenance Studies. Geological Society, London. Special Publications, 57, 161-172.

FLOYD, J.D. 1994. The derivation and definition of the 'Southern Upland Fault': a review of the Midland Valley-Southern Uplands terrane boundary. Scottish Journal of Geology, 30, 51-62.

FLowerdew, M.J. 1999. Tonalite bodies and basement-cover relationships in the northeastern Ox Mountains Inlier, north-western Ireland. Irish Journal Earth Sciences, 17, 71-82.

Fortey, R.A., Harper, D.A.T., Ingham, J.K., Owen, A.W. \& Rushton, A.W.A. 1995. A revision of the Ordovician Series and Stages in the historical type area. Geological Magazine, 132, 15-30.

Fortey, R.A., Harper, D.A.T., Ingham, J.K., Owen, A.W., Parkes, M.A., Rushton, A.W.A. \& Woodcock, N.H. 2000. A revised correlation of Ordovician rocks in the British Isles. Geological Society, London. Special Reports, 24

Gibbons, W. \& Gayer, R.A. 1985. British Caledonian Terranes. In: Gayer, R.A. (ed.) The Tectonic Evolution of the Caledonian-Appalachian Orogen. Friedr Vieweg \& Sons, Braunschweig/Weisbaden, 3-16.

Hall, J., Brewer, J.A., Matthews, D.H. \& Wagner, M.R. 1984. Crustal structure across the Caledonides from 'WINCH' seismic reflection profile: influences on the evolution of the Midland valley of Scotland. Transactions of the Royal Society of Edinburgh: Earth Sciences, 75, 97-109.

Harper, D.A.T. \& Parkes, M.A. 1989. Palaeontological constraints on the definition and development of Irish Caledonide terranes. Journal of the Geological Society, London, 146, 413-415.

Harris, P.M., Farrar, E., Macintyre, R.M., York, D. \& Miller, J.A. 1965. Potassium-argon age measurements on two igneous rocks from the Ordovician system of Scotland. Nature, 205, 352-353.

Haughton, P.D.W. 1988. A cryptic Caledonian flysch terrane in Scotland. Journal of the Geological Society, London, 145, 685-703.

Haughton, P.D.W. \& Halliday, A.N. 1991. Significance of late Caledonian igneous complex revealed in the Lower Old Red Sandstone conglomerates, central Scotland. Geological Society of America Bulletin, 103, 14761492.

Hughes, R.A. \& KoKelaar, P. 1993. The timing of Ordovician magmatism in the English Lake District and Cross Fell inliers. Geological Magazine, 130, 369-377.

Hutchison, A.R. \& Oliver, G.J.H. 1998. Garnet provenance studies, juxtaposition of Laurentian marginal terranes and timing of the Grampian Orogeny in Scotland. Journal of the Geological Society, London, 155, $541-550$.

Hutton, D.H.W. 1987. Strike-slip terranes and a model for the evolution of the British and Irish Caledonides. Geological Magazine, 124, 405-425.

Hutton, D.H.W. \& Dewey, J.F. 1986. Strike-slip terrane accretion in the western Irish Caledonides. Tectonics, 5, 1115-1124.

Hutton, D.H.W. \& Holland, C.H. 1992. An Arenig-Llanvirn age for the Black Shales of Sleive Gallion, County Tyrone. Irish Journal of Earth Sciences, 11, 187-189.

Hutton, D.H.W. \& McErLEan, M. 1991. Silurian and Early Devonian sinistral deformation of the Ratagain granite, Scotland; Constraints on the age of Caledonian movements on the Great Glen fault system. Journal of the Geological Society, London, 148, 1-4.

Hutton, D.H.W., Aftalion, M. \& Halliday, A.N. 1985. An Ordovician ophiolite in County Tyrone, Ireland. Nature, 315, 210-212.

INCE, D. 1984. Sedimentation and tectonism in the Middle Ordovician of the Girvan district, SW Scotland. Transactions of the Royal Society of Edinburgh: Earth Sciences, 75, 225-237.

InGHAM, J.K. 1978. Geology of a continental margin 1: middle and late Ordovician transgression. In: Bowes, D.R. \& LeAKE, B.E. (eds) Crustal evolution in northwestern Britain and adjacent regions. Geological Journal, Special Issues, 10, 163-176.

Ingham, J.K., Curry, G.B. \& Williams, A. 1986. Early Ordovician Dounan Limestone fauna, Highland Border Complex, Scotland. Transactions of the Royal Society of Edinburgh: Earth Sciences, 76, 481-513.

Johnson, J.D. \& PhiLlips, W.E.A. 1995. Terrane amalgamation in the Clew Bay region, west of Ireland. Geological Magazine, 132, 485-501.

KelLey, S. \& BlucK, B.J. 1989. Detrital mineral ages from the Southern Uplands using ${ }^{40} \mathrm{Ar}^{-39} \mathrm{Ar}$ laser probe. Journal of the Geological Society, London, 146, 401-403.
Kelley, S. \& BLuCK, B.J. 1990. Reply to discussion on detrital mineral ages from the Southern Uplands using ${ }^{40} \mathrm{Ar}-{ }^{39} \mathrm{Ar}$ laser probe. Journal of the Geological Society, London, 147, 883-884.

Kelling, G., Davies, P. \& Holroyd, J. 1987. Style, scale and significance of sandbodies of the Northern and Central Belts, southwest Southern Uplands. Journal of the Geological Society, London, 144, 787-805.

Kimbell, G.S. \& Stone, P. 1995. Crustal magnetization variations across the Iapetus Suture Zone. Geological Magazine, 132, 599-609.

KLempereR, S.L. \& Matthews, D.H. 1987. Iapetus Suture located beneath the North Sea by BIRPS deep seismic reflection profiling. Geology, 15 , 195-198.

KOKelaAR, B.P. 1988. Tectonic controls of Ordovician arc and marginal basin volcanism in Wales. Journal of the Geological Society, London, 145, 759-775.

Longman, C.D. 1980. Age and affinity of granitic detritus in Lower Palaeozoic conglomerates $S$. W. Scotland: implications for Caledonian evolution. $\mathrm{PhD}$ thesis. University of Glasgow.

McCaffrey, W.D. \& KNelLeR, B.C. 1996. Silurian turbidite provenance on the northern Avalonian margin. Journal of the Geological Society, London, $\mathbf{1 5 3}$ 437-450.

McKerrow, W.S., Lambert, R.St.J. \& Cocks, L.R.M. 1985. The Ordovician, Silurian and Devonian periods. In: SNELLING, N.J. (ed.) The Chronology of the Geological Record. Geological Society, London Memoirs, 10, 73-80.

Merriman, R.J. \& Frey, M. 1999. Patterns of very low-grade metamorphism in metapelitic rocks. In: Frey, M. \& Robinson, D. (eds) Low-Grade Metamorphism. Blackwell Science, Oxford, 61-108.

Morris, J.H. 1987. The Northern Belt of the Longford-Down Inlier, Ireland and the Southern Uplands, Scotland: an Ordovician back-arc basin. Journal of the Geological Society, London, 144, 773-786.

Murphy, F.C. \& Hutton, D.H.W. 1986. Is the Southern Uplands of Scotland really an accretionary prism? Geology, 14, 354-357.

Murphy, F.C., ANDERSEN, T.B. et al. 1991. An appraisal of Caledonian suspect terranes in Ireland. Irish Journal of Earth Sciences, 11, 11-41.

Murray, R.W., Buchholtz ten Brink, M.R., Gerlach, D.C., Russ, D.P. \& JONES, D.L. 1992. Interoceanic variation in the rare earth, major, and trace element depositional chemistry of chert: Perspectives gained from the DSDP and ODP record. Geochimica et Cosmochimica Acta, 56, 1897-1913.

Oliver, G.J.H., Chen, F., Buchwaldt, R. \& Hegner, E. 2000. Fast tectonometamorphism and exhumation in the type area of the Barrovian and Buchan Zones. Geology, 28, 459-462.

Owen, A.W. \& PARKES, M.A. 2000. Trilobite faunas of the Duncannon Group: Caradoc stratigraphy, environments and palaeobiogeography of the Leinster terrane, Ireland. Palaeontology, 43, 219-271.

Owen, A.W., Harper, D.A.T. \& Romano, M. 1992. The Ordovician biogeography of the Grangegeeth terrane and the Iapetus suture zone in eastern Ireland. Journal of the Geological Society, London, 149, 3-6.

Owen, A.W., Armstrong, H.A. \& Floyd, J.D. 1999. Rare Earth Element geochemistry of upper Ordovician cherts from the Southern Uplands. Journal of the Geological Society, London, 156, 191-204.

Phillips, E.R., Barnes, R.P., Merriman, R.J. \& Floyd, J.D. 1995a. The tectonic significance of Ordovician basaltic rocks in the Southern Uplands, SW Scotland. Geological Magazine, 132, 549-556.

Phillips, E.R., Barnes, R.P., Boland, M.P., Fortey, N.J. \& McMillan, A.A. 1995b. The Moniaive Shear Zone: a major zone of sinistral strike-slip deformation in the Southern Uplands of Scotland. Scottish Journal of Geology, 31, 139-149.

Phillips, E.R., SMith, R.A. \& Carroll, S. 1998. Strike-slip, terrane accretion and pre-Carboniferous evolution of the Midland Valley of Scotland Transactions of the Royal Society Edinburgh: Earth Sciences, 89, 209-224.

Phillips, E.R., Sмith, R.A. \& FLoyd, J.D. 1999. The Bail Hill Volcanic group: alkaline within-plate volcanism during Ordovician sedimentation in the Southern Uplands, Scotland. Transactions of the Royal Society of Edinburgh: Earth Sciences, 89 [for 1998], 233-247.

Pickering, K.T., Bassett, M.G. \& Siveter, D.J. 1988. Late Ordovician-Early Silurian destruction of the Iapetus Ocean: Newfoundland, British Isles and Scandinavia: A discussion. Transactions of the Royal Society of Edinburgh: Earth Sciences, 79, 361-382.

Prave, A.R., Kessler, L.G., Malo, M., Bloechl, W.V. \& Riva, J. 2000 Ordovician arc collision and foredeep evolution in the Gaspé Peninsula, Québec: the Taconic Orogeny in Canada and its bearing on the Grampian Orogeny in Scotland. Journal of the Geological Society, London, 157, 393-400.

Robertson, G. 1989. A palaeoenvironmental interpretation of the Silurian rocks of the Pentland Hills, near Edinburgh. Transactions of the Royal Society of Edinburgh: Earth Sciences, 80, 127-141. 
Romano, M. 1980. The stratigraphy of the Ordovician rocks between Slane (County Meath) and Collon (County Louth), eastern Ireland. Journal of Earth Sciences, Royal Dublin Society, 3, 53-79.

Romano, M. \& Owen, A.W. 1993. Early Caradoc trilobites of eastern Ireland and their palaeogeographical significance. Palaeontology, 36, 681-720.

Rushton, A.W.A. 1997. Trichograptus from the Lower Arenig of Kiltrea, County Wexford. Irish Journal of Earth Sciences, 15 [for 1996], 61-69.

Rushton, A.W.A. \& Tripp, R.P. 1979. A fossiliferous lower Canadian (Tremadoc) boulder from the Benan Conglomerate of the Girvan district. Scottish Journal of Geology, 15, 321-327.

Rushton, A.W.A., Stone, P. \& Hughes, R.A. 1996. Biostratigraphical control of thrust models for the Southern Uplands of Scotland. Transactions of the Royal Society of Edinburgh: Earth Sciences, 86, 137-152.

Ryan, P.D. \& Dewey, J.F. 1991. A geological and tectonic cross-section of the Caledonian of western Ireland. Journal of the Geological Society, London, 148, 173-180.

Schubert, G., Yuen, D.A. \& Turcotte, D.L. 1975. Role of phase transitions in the dynamic mantle. Geophysical Journal of the Royal Astronomical Society, 42, 705-735.

Scott, J.G. 1966. Regional Archaeologies: South-West Scotland. Heinemann, London.

Scrutton, C.T.S., Jeram, A.J. \& Armstrong, H.A. 1998. Kilbuchophyllid corals from the Ordovician (Caradoc) of Pomeroy, Co. Tyrone: implications for coral phylogeny and for movement on the Southern Uplands Fault. Transactions of the Royal Society of Edinburgh: Earth Sciences, $\mathbf{8 8}$ [for 1997], 117-126.

Smellie, J.L. \& Stone, P. 1992. Geochemical control on the evolutionary history of the Ballantrae Complex, SW Scotland, from comparisons with recent analogues. In: PArson, L.M., Murton, B.J. \& Browning, P. (eds) Ophiolites and their Modern Oceanic Analogues. Geological Society, London. Special Publications, 60, 171-178.

Smith, R.A. 1995. The Siluro-Devonian evolution of the Southern Midland Valley of Scotland. Geological Magazine, 132, 503-513.

Soper, N.J. \& Hutton, D.H.W. 1984. Late Caledonian sinistral displacements in Britain: implications for a three plate collision model. Tectonics, $\mathbf{3}$, 781-794.

Soper, N.J., Strachan, R.A., Holdsworth, R.E.H., Gayer, R.A. \& Greiling, R.O. 1992. Sinistral transpression and the closure of Iapetus. Journal of the Geological Society, London, 149, 871-880.

Soper, N.J., Ryan, P.D. \& Dewey, J.F. 1999. Age of the Grampian Orogeny in Scotland and Ireland. Journal of the Geological Society, London, 156, 1231-1236.

STEIGER, R.H. \& JäGER, E. 1977. Subcommission on geochronology: convention on the use of decay constants in geo- and cosmochronology. Earth and Planetary Science Letters, 60, 359-362.

Stone, P. 1995. Geology of the Rhinns of Galloway district. Memoir of the British Geological Survey. sheets 1 and 3 (Scotland).

Stone, P. \& Evans, J.A. 1999. Discussion on garnet provenance studies, juxtaposition of Laurentian marginal terranes and the timing of the Grampian Orogeny in Scotland. Journal of the Geological Society, London, 156, 205-207.

Stone, P. \& Kimbell, G.S. 1995. Caledonian terrane relationships in Britain: an introduction. Geological Magazine, 132, 461-464.

Stone, P. \& Rushton, A.W.A. 1983. Graptolite faunas from the Ballantrae ophiolite complex and their structural implications. Scottish Journal of Geology, 19, 297-310.

Stone, P. \& Smellie, J.L. 1990. The Ballantrae Ophiolite, Scotland: an Ordovician island arc-marginal basin assemblage. In: Malpas, J., Moores, E.M., Panayiotou, A. \& Xenophontos, C. (eds) Ophiolites: oceanic and crustal analogues. Geological Survey Department, Nicosia, Cyprus, 535-546.

Stone, P., Floyd, J.D., Barnes, R.P. \& Lintern, B.C. 1987. A sequential back-arc and foreland basin thrust duplex model for the Southern Uplands of Scotland. Journal of the Geological Society, London, 144, $753-764$.

Stone, P., Kimbell, G.S. \& Henney, P.J. 1997. Basement control on the location of strike-slip shear in the Southern Uplands of Scotland. Journal of the Geological Society, London, 154, 141-44.

Stone, P., Cooper, A.H. \& Evans, J.A. 1999a. The Skiddaw Group (English Lake District) reviewed: early Palaeozoic sedimentation and tectonism at the northern margin of Avalonia. In: Woodcock, N.H., Quirk, D.G.,
Fitches, W.R. \& Barnes, R.P. (eds) In Sight of the Suture: the Palaeozoic geology of the Isle of Man in its Iapetus Ocean context. Geological Society, London. Special Publications, 160, 325-36.

Stone, P., Plant, J.A., Mendum, J.R. \& Green, P.M. 1999b. A regional geochemical assessment of some terrane relationships in the British Caledonides. Scottish Journal of Geology, 35, 145-156.

Stouge, S. \& Bagnoli, G. 1990. Lower Ordovician (Volkhovian-Kundan) conodonts from Hagudden, northern Öland, Sweden. Paleontographia Italica, 77, 1-54.

Teitzsch-Tyler, D. 1996. Precambrian and Early Caledonian orogeny in south-east Ireland. Irish Journal of Earth Sciences, 15, 19-39.

Thirlwall, M.F. 1988. Geochronology of British Late Caledonian magmatism in northern Britain. Journal of the Geological Society, London, 145 951-967.

Torsvik, T.H., Smethurst, M.A., Meert, J.G., Van der Voo, R., McKerrow, W.S., Brasier, M.D., Sturt, B.A. \& Walderhaug, H.J. 1996. Continental break-up and collision in the Neoproterozoic and Palaeozoic-A tale of Baltica and Laurentia. Earth Science Reviews, 40, 229-258.

Upton, B.J.G., Aspen, P. \& Chapman, N.A. 1983. The upper mantle and deep crust beneath the British Isles: evidence from inclusions in volcanic rocks. Journal of the Geological Society, London, 140, 105-121.

VAn StaAl, C.R. 1994. The Brunswick subduction complex in the Canadian Appalachians: record of the Late Ordovician to Late Silurian collision between Laurentia and the Gander margin of Avalon. Tectonics, 13, 946-962.

van Staal, C.R., Winchester, J.A. \& Bedard, J.H. 1991. Geochemical variations in Ordovician volcanic rocks of the northern Miramichi Highlands and their tectonic significance. Canadian Journal of Earth Sciences, 28, 1031-1049.

van Staal, C.R., Sullivan, R.W. \& Whalen, J.B. 1996. Provenance and tectonic history of the Gander margin in the Caledonian/Appalachian Orogen: implications for the origin and assembly of Avalonia. In: NANCE, D. \& Thompson, M. (eds) Avalonian and related Peri-Gondwanan Terranes of the Circum-North Atlantic. Geological Society of America Special Paper, 304, 347-367.

van Staal, C.R., Dewey, J.F., Mac Niocalll, C. \& McKerrow, W.S. 1998. The Cambrian-Silurian tectonic evolution of the northern Appalachians and British Caledonides: history of complex, west and southwest Pacifictype segment of Iapetus. In: BLundell, D.J. \& ScOTT, A.C. (eds) Lyell: the Past is the Key to the Present. Geological Society, London. Special Publications, 143, 199-242.

Watson, J. 1984. The ending of the Caledonian orogeny in Scotland. Journal of the Geological Society, London, 141, 193-214.

Williams, A. 1962. The Barr and Lower Ardmillan Series (Caradoc) of the Girvan district, south-west Ayrshire, with descriptions of the Brachiopoda. Memoir of the Geological Society, London, 3.

Williams, H. 1978. Geological development of the northern Appalachians: its bearing on the evolution of the British Isles. In: Bowes, D.R. \& LEAKE, B.E. (eds) Crustal evolution in northwest Britain and adjacent regions. Geological Journal Special Issue, 10, 1-22.

Williams, H. \& Hatcher, R.D. 1982. Suspect terranes and accretionary history of the Appalachian orogen. Geology, 10, 530-536.

Williams, S.H., Boyce, W.D. \& Colman-SadD, S.P. 1992. A new Lower Ordovician (Arenig) faunule from the Coy Pond Complex, central Newfoundland, and a refined understanding of the closure of the Iapetus Ocean. Canadian Journal of Earth Sciences, 29, 2046-2057.

Williams, S.H., Harper, D.A.T., Neuman, R.B., Boyce, W.D. \& MaC Niocaill, C. 1995. Lower Palaeozoic fossils from Newfoundland and their importance in understanding the history of the Iapetus Ocean. In: Hibbard, J.P., van StaAl, C.R. \& Cawood, P.A. (eds) Current perspectives in the Appalachian-Caledonian Orogen. Geological Association of Canada Special Papers, 41, 115-126.

Williams, T.M., Henney, P.J., Stone, P. \& Lintern, B. 1996. Rare earth element geochemistry of Lower Palaeozoic turbidites in the British transIapetus zone: provenance patterns and basin evolution. Scottish Journal of Geology, 32, 1-8.

Winchester, J.A. \& van StaAl, C.R. 1994. The chemistry and tectonic setting of Ordovician volcanic rocks in northern Maine and their relationships with contemporary volcanic rocks in northern New Brunswick. American Journal of Science, 294, 641-662. 